\title{
Connective tissue, glial and neuronal expressions in testis of the African giant rat (Cricetomys gambianus)
}

\author{
FALADE, T. E. ${ }^{1}$, OLUDE, M. A. ${ }^{2}$, MUSTAPHA, O. A. ${ }^{2}$, MBAJIORGU, E. F. ${ }^{3}$, \\ IHUNWO, A. O. ${ }^{3}$, OLOPADE, J. O. ${ }^{1}$ and OKE, B. O. ${ }^{1}$ \\ ${ }^{1}$ Department of Veterinary Anatomy, Faculty of Veterinary Medicine, University of Ibadan, Oyo Road, \\ P.M.B. 5116, Ibadan, 20001, Oyo State, Nigeria \\ ${ }^{2}$ Department of Veterinary Anatomy, College of Veterinary Medicine, Federal University of Agriculture, \\ Alabata Road, P.M.B. 2240, Abeokuta, 110222, Ogun State, Nigeria \\ ${ }^{3}$ School of Anatomical Sciences, Faculty of Health Sciences, University of the Witwatersrand, 7 York Road, \\ Parktown 2193, Johannesburg, South Africa \\ *E-mail: faladetemitope21@yahoo.com
}

\begin{abstract}
Introduction: This study was carried out to investigate the expression of connective tissue (Collagens I and III), glia and neuronal markers in the testis of the African giant rat using histology and immunohistochemistry techniques. Materials and Methods: Eight (8) apparently healthy wild male African giant rats were used for this experiment, divided into 2 groups (juvenile and adult) of 4 animals each. The testes were harvested following intracardial perfusion of the rats and histology was performed using Haematoxylin-Eosin stain and Mallory-Heideinhain rapid one- step staining for connective tissue. Immunohistochemical identification was achieved using the following antibodies: anti-collagen type I, anti-collagen type III, anti-glial fibrillary acidic protein and anti-p75 nerve growth factor for the expression of collagen type I, collagen type III, astrocyte-like cell and neuronal cells respectively. Photomicrography was achieved using Axioskop ${ }^{\circledR}$ microscope and quantitative data were analyzed using student t-test. Results: The cyto-architecture of the testis was typical in the African giant rat. The connective tissue expressed in the juvenile and adult group, signaling of glial-like cells were seen in the perivascular region across the experimental groups. Immuno-localization of neuronal cells were seen in the interstitial spaces across all the groups, but with more expressions in the juvenile. Conclusion: This work has provided a clear description of the expression of connective tissue, neuronal and glial cells in the testis of the African giant rat and their possible relationships across juvenile and adult groups.
\end{abstract}

Keywords: African giant rat, collagen, glia, neuron, testis.

\section{Introduction}

The African giant rat, AGR (Cricetomys gambianus, Waterhouse), is one of Africa's largest rodents valued as an important food item (JOO, 2004). They are highly prolific breeders producing several litters all year round, with the testicular structure and functions demonstrated to play vital roles in this fecundity (OKE, 1985, 1988).

The mammalian testis essentially consists of seminiferous tubules enmeshed in a web of loose connective tissue, rich in blood and lymphatic vessels, nerves and interstitial (Leydig) cells (JUNQUEIRA and CARNEIRO, 2007). Leydig cells constitute the endocrine component that synthesize and secrete testosterone, while Sertoli cells provide mechanical and nutritive support for the spermatogenic cells, and also function in blood-testis barrier (BTB) (ROBILLARD, HOQUE and BENDAYAN, 2012). These interstitial components have been shown to have significant impact on reproductive health in mammals. For instance, the BTB acts as the "fence" and "gate-keeper" protecting the testis from the vagaries of systemic circulation and thus, possess physically restrictive characteristics that filter the entry and exit of molecules (CHENG and MRUK, 2012). The BTB also confers cell polarity in the seminiferous epithelium; creates an immunological barrier and is necessary for spermatogonial stem cell differentiation during spermatogenesis in the testis (CHENG and MRUK, 2012; FIJAK, BHUSHAN and MEINHARDT, 2011). It has been proposed that most testicular capillaries contribute to this barrier by complementing the epithelial components formed by the tight junctions of apposing Sertoli cells (HOLASH, HARIK, PERRY et al., 1993). Testicular microvessels are endowed with several markers of barrier properties. High density of GLUT-1, a glucose transporter, in the testicular endothelium may be a necessary marker for barrier endothelium, suggesting the probable role of testicular endothelium in the BTB. The contribution of Leydig cells to the BTB has been demonstrated in the rat testis (HOLASH, HARIK, PERRY et al., 1993), where they are thought to be analogues of astrocytes because of their intimate proximity to testicular microvessels, their ectodermal origin, and their biochemical and cytoskeletal similarities in their expression for astrocyte markers. Thus, they function, in part, to induce and/or maintain barrier features in testicular capillaries (HOLASH, HARIK, PERRY et al., 1993; ROBILLARD, HOQUE and BENDAYAN, 2012).

In the central and peripheral nervous systems, glia cells are usually located alongside nerves as support cells. Astrocytes in particular, serve various functions among which is the maintenance of blood-brain barrier (PASQUINI, SPURGEON 
and PASQUINI, 1997). Glial Fibrillary Acidic Protein (GFAP) is an intermediate filament, expressed in astrocytes (SOFRONIEW and VINTERS, 2010) and in non-myelination forming Schwann cells (HOMMA, BEERMANN and MILLER, 2011). It has also been demonstrated in a number of non-nervous tissues amongst which are the Leydig cells of the rat and human testes (HOLASH, HARIK, PERRY et al., 1993; DAVIDOFF, MIDDENDORFF, KÖFÜNCÜ et al., 2002). Collagen on the other hand, is the most abundant structural protein in the extracellular matrix of various connective tissues with the principal function of providing tensile strength and structural support for other tissues and organs in the body (DI LULLO, SWEENEY, KÖRKKÖ et al., 2002; YOUNG, LOWE, STEVENS et al., 2013). Different collagen types have been identified, with types I, II and III being the most abundant (LODISH, BERK, MATSUDAIRA et al., 2003). Interstitial collagen type I and III distribution in the developing rat testis reveals a correlation between the differentiation, organization, and abundance of the mesenchyme and the differentiation of the testicular cords (PARANKO, 1987).

This paper aims at providing information on the nervous, glial and connective tissue infrastructure of the testis of the African giant rat, with suggestions in their possible roles in AGR spermatogenesis, as part of study involving this species of rodent which is eaten in many parts of West Africa and is increasingly being used as research animal models in reproduction.

\section{Materials and Methods}

Eight (8) apparently healthy male African giants rats ( 4 juveniles and 4 adults) were acquired from the wild by local hunters in Ibadan, Oyo State located within the South-Western region of Nigeria. Age estimations and classifications as juveniles (between $70 \mathrm{~g}$ and $500 \mathrm{~g}$ ) and adults (above $500 \mathrm{~g}$ ) were done in accordance with the study of Ajayi (1974). These rats were transported in ventilated metal cages to the Animal House, Faculty of Veterinary Medicine, University of Ibadan, Ibadan; where they were stabilized, housed and fed ad libitum for 3 days. All animals were sedated (Ketamine $10 \mathrm{mg} / \mathrm{kg}$ intramuscular) and perfused transcardially, first with normal saline and then followed by $4 \%$ Phosphate Buffered Formalin (PBF). Thereafter, both right and left testes of all animals were surgically excised, post-fixed in 4\% PBF for 48 hours, and then changed to $1 \%$ Sodium Azide in 1 M PBS until ready for tissue preparation into paraffin blocks. Processed paraffin blocks were sectioned at $5 \mu \mathrm{m}$ thickness and stained with Haematoxylin and Eosin (H\&E) and Mallory-Heideinhain rapid one-step staining procedures.

Immunohistochemistry (IHC): Sections were dewaxed in two changes of xylene for 5 minutes each, rehydrated in decreasing concentrations of ethanol $(100 \%, 100 \%$, and $95 \%$ ) for 30 seconds each, followed by washing of slides in running water for 5 minutes. Antigen retrieval was achieved in $10 \mathrm{mM}$ Sodium Citrate buffer, $\mathrm{pH} 6(720 \mathrm{~W})$ for 10 minutes and allowed to cool at room temperature for 20 minutes. The slides were then washed in TBS, pH 7.4 for 5 minutes. Endogenous peroxidase was blocked with $1 \% \mathrm{H}_{2} \mathrm{O}_{2}$ in methanol for 15 minutes at room temperature; washed in 3 changes of TBS for 5 minutes each. All sections were then incubated in $5 \%$ normal goat serum $(100 \mu \mathrm{L}$ per section) for 45 minutes. Sections were then incubated overnight at $4^{\circ} \mathrm{C}$ with primary antibodies, anti-GFAP and anti-p75 nerve growth factor, NGF (abcam, ab 7260 and ab 8874; 1:2000 and 1:700 dilution factors respectively) diluted in TBS.

Anti-GFAP and anti-p75 NGF: Sections were allowed to acclimatize to room temperature for 10 minutes and then gently washed thrice in TBS for 5 minutes at room temperature. The sections were incubated with biotinylated secondary antibody, goat anti-rabbit (Vector Laboratories, Inc; Burlingame, CA; 1:1000 dilution factor) for 30 minutes; after which they were washed in 3 changes of TBS for 5 minutes each. Slides were incubated with Avidin Biotin Complex (ABC) reagent in TBS (Vector Laboratories, VectaStain ${ }^{\circledR} \mathrm{ABC}$ kit) $25 \mu \mathrm{l}$ of A $+25 \mu \mathrm{l}$

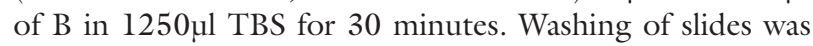
later done in TBS 3 times for 5 minutes each, incubated with DAB (Sigma-Aldrich ${ }^{\circledR}$ ) solution for 5 minutes, and rinsed in running water for 5 minutes.

Anti-collagen I and anti-collagen III: Sections were brought out from $4{ }^{\circ} \mathrm{C}$, and allowed to acclimatize to room temperature for 10 minutes. Washing was done 4 times in PBS for 5 minutes each. The slides were incubated with secondary antibody, (Biotinylated goat anti-rabbit, abcam kit, ab 64261; dropped directly on each section) for 10 minutes. They were then washed thrice in PBS for 5 minutes each under gentle shaking at room temperature. Incubation with StreptAvidin HRP, horse radish peroxidase (abcam kit, ab 64261) was done by directly applying the kit straight to the sections and incubated for 30 minutes. Slides were later washed in 3 changes of PBS for 5 minutes each, incubating with DAB (abcam kit, ab 64261; 50 drops of DAB substrate +1 drop chromogen) for 5 minutes. The reaction was stopped by rinsing the slides in running tap water for 5 minutes. Counter-staining was performed for all sections in haematoxylin for 30 seconds and excess stain was washed off under running water for 5 minutes. Subsequently, the sections were dehydrated rapidly through increasing grades of ethanol $(95 \%, 100 \%$ and $100 \%$ ) for 30 seconds each; and then cleared in 2 changes of xylene for 5 minutes each. The sections were then mounted with Entellan ${ }^{\circledR}$, cover-slipped and allowed to dry. Digital Photomicrographs were captured using Zeiss Axioskop 2 plus ${ }^{\circledR}$ and Zen ${ }^{\circledR}$ softwares. Three testicular parameters (seminiferous tubular diameter, germinal height and luminal diameter) were measured (in microns) and expressed as mean \pm SEM. Quantitation of IHC signal intensities was performed using Image J software (1.46r version) and results represented in bar charts. All quantitative data obtained were statistically evaluated, comparing between the juvenile and adult groups, with Graphpad Prism 4 system using unpaired Student's t-test (two-tailed). Statistical significance was reported at $\mathrm{p}<0.05$.

\section{Results}

Histological studies: The cross sections of the testes were typical for rodents with H\&E stain (Figure 1A). The lumen of the seminiferous tubules of the juvenile AGR had little or no spermatozoa compared to those of the adults (Figures IB and 1C).

Connective Tissue Studies (Collagen Stain: Mallory-Heideinnain stain): The testis of the juvenile AGR stained with varying shades of blue indicating the ground substance, mucus, amyloid 

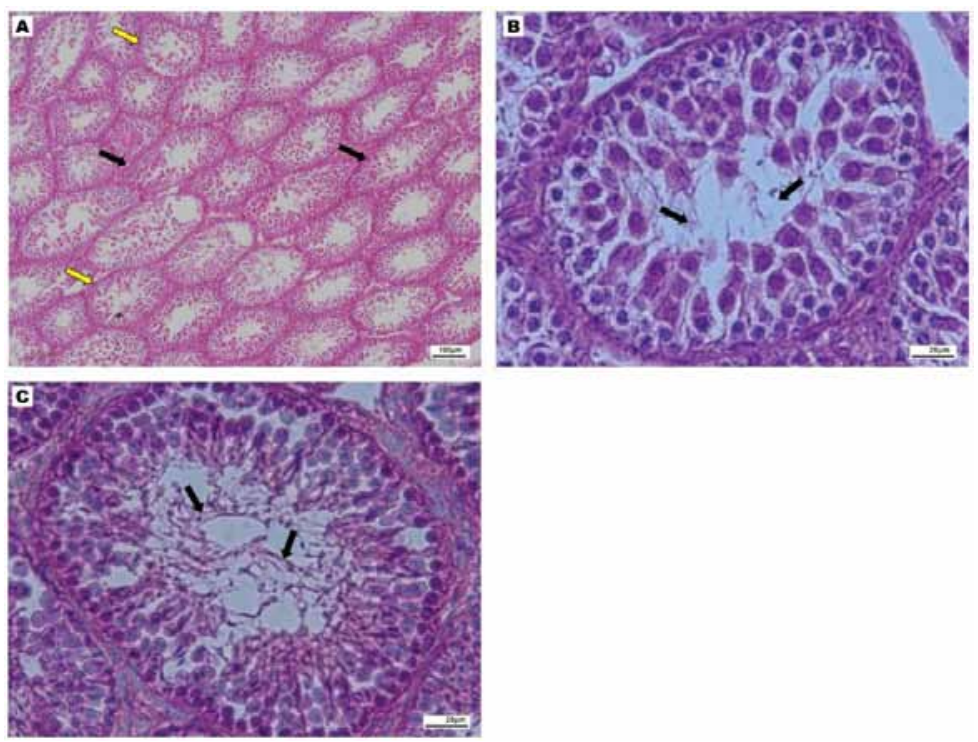

Figure 1. Representative H \& E photomicrographs of the AGR testis showing: (A) numerous seminiferous tubules across the testicular section in the juvenile AGR. Some of the tubules are roundish (yellow arrows), while some appear to be oval (black arrows) Mag. x100; (B) Cytoarchitecture of juvenile AGR testis with spermatogenic series arranged from the basement membrane to the lumen. Notice the little or no spermatozoa in the lumen (black arrows) Mag. x630; (C) Cytoarchitecture of the adult AGR testis. Observe numerous spermatozoa in the lumen of the seminiferous tubule (black arrows) Mag. x630.
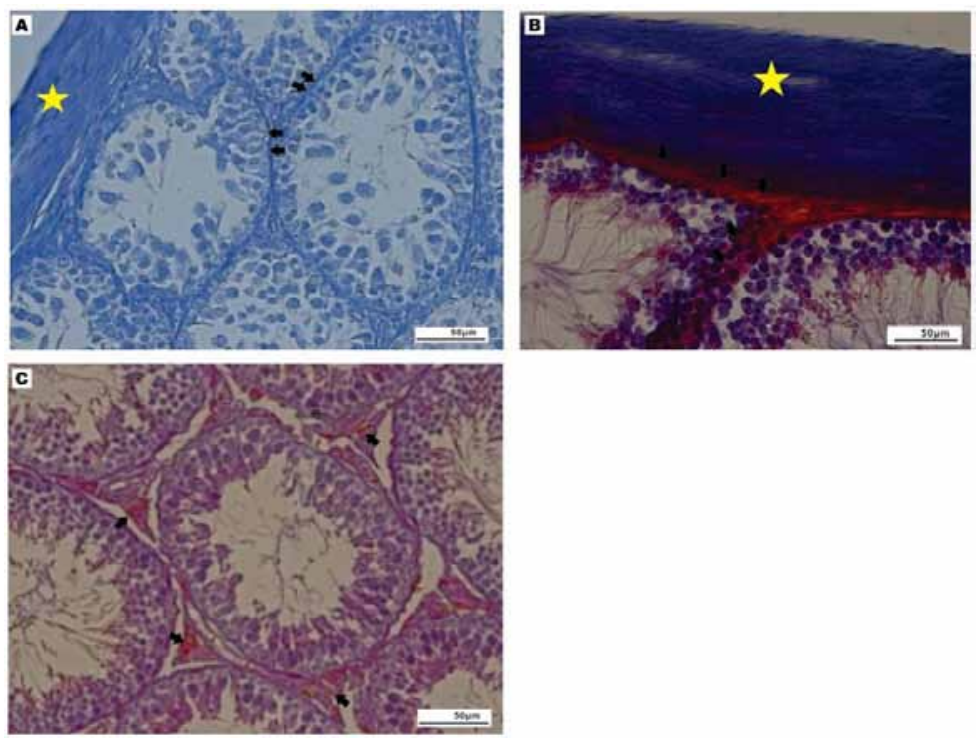

Figure 2. Representative photomicrographs (Mag. x400) with Mallory-Heideinhain stain showing (A) the connective tissue stain across the testicular tissue in the juvenile AGR. Note the varying shades of blue staining at the testicular capsule (star), and basement membrane of the seminiferous tubules (arrows); (B) connective tissue stain across the testicular tissue in the adult AGR. Note the intense blue staining in the testicular capsule (star), and the red stained basement membrane of the seminiferous tubules (arrows). The intense blue stained for collagen (star), while the red stained for myoglia and neuroglia fibres (arrows); (C) testicular interstitial spaces (arrows) of the adult AGR stained red highlighting myoglia and neuroglia fibres.

and certain hyaline substances (Figure 2A). The adult testicular tissue showed heterogenic staining pattern; the testicular capsule stained intense blue indicating the presence of collagen fibre while myoglia and neuroglia fibres at the basement membrane of the seminiferous tubules, and the interstitial spaces of testicular tissues stained red (Figures $2 \mathrm{~B}$ and 2C).

Histomorphometry (Seminiferous tubular diameter): The seminiferous tubular diameter and luminal diameter of the adult AGR was significantly higher than that of the juvenile group (Figures $3 \mathrm{~A}$ and $3 \mathrm{~B}$ ). However, there was no statistically significant difference in the germinal heights of the seminiferous tubules between both groups (Figure 3C).

Collagen Type I Studies: Regional expressions of collagen type I in the juvenile group were seen at the basement membrane of the seminiferous tubule as well as the interstitial spaces and cytoplasm of the spermatocytes. It was however more evident at the testicular capsule (Figure 4A). A similar but stronger expression pattern was observed in the adult group, with 
A

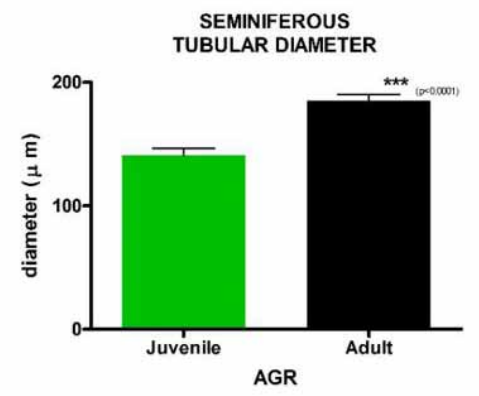

○

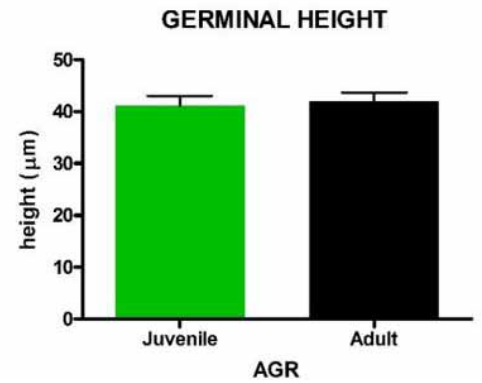

B.

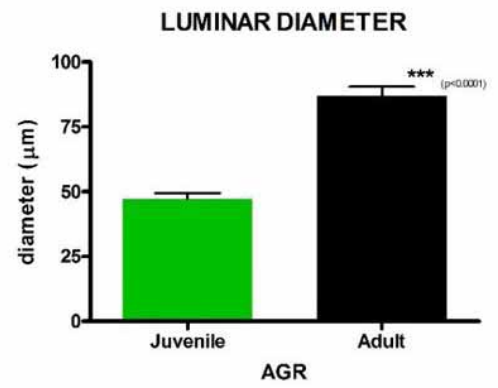

Figure 3. Comparison of selected testicular histomorphometric parameters between juvenile and adult AGR. (A) Seminiferous tubular diameter; (B) Seminiferous luminal diameter; (C) Germinal height of seminiferous tubules. Values are expressed as mean \pm SEM using 4 slides per group. ${ }^{* *}$ Represents statistical significant difference.

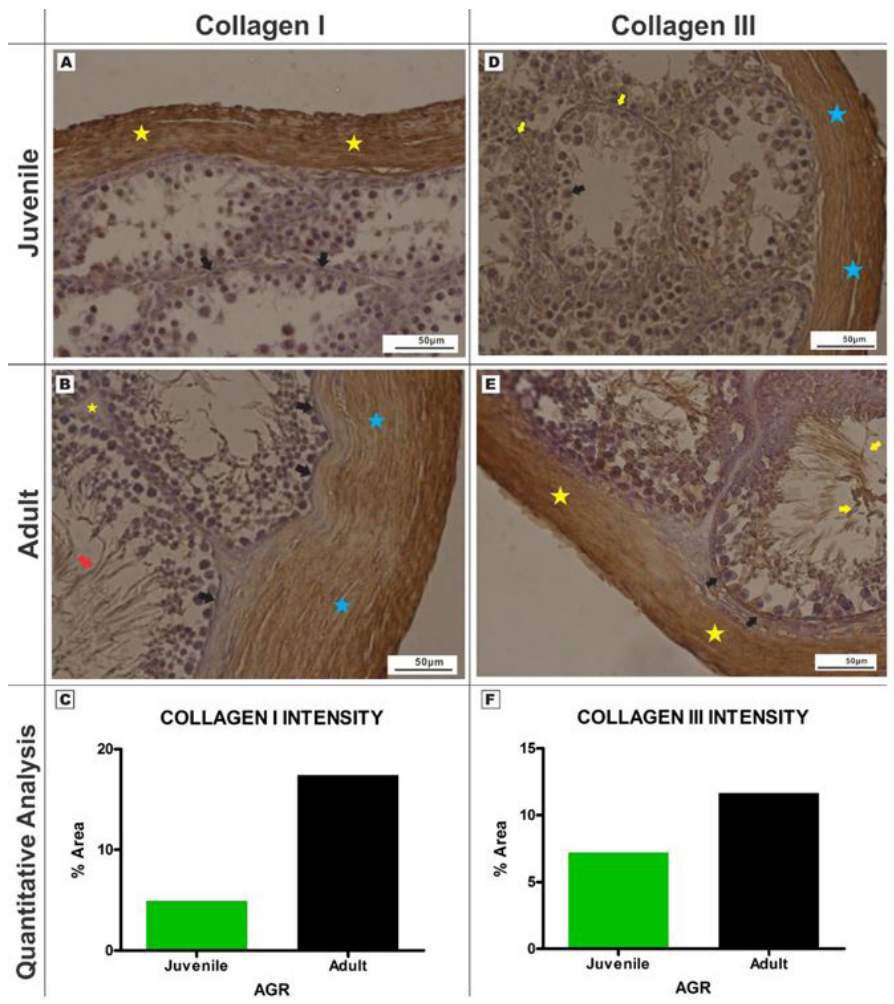

Figure 4. Immnunolocalization and Quantification of Collagen I and III types in AGR testis (Mag. x400). COLLAGEN TYPE I: (A) Juvenile - immunopositive signalling for collagen type I in the testicular capsule (yellow stars) and basement membrane (black arrows) of the seminiferous tubules; (B) Adult - positive signalling for collagen type I in the testicular capsule (blue stars), basement membrane of the seminiferous tubules (black arrows), in the interstitial spaces of the tubules (yellow star) and spermatozoa (red arrow); (C) Quantitative analysis of collagen types I and III signal intensities in AGR testis between juvenile and adult groups showed greater signal values per unit area in the adult using 4 slides per group. COLLAGEN TYPE III: (D) Juvenile - Immunopositive collagen type III expressions at the testicular capsule (blue stars), around the basement membranes (yellow arrows) and in primary spermatocytes (black arrow); (E) Adult - collagen type III expressions in the testicular capsule (yellow star), basement membranes (black arrows) and spermatozoa (yellow arrows); (F) Quantitative evaluation of collagen type III in the AGR testis using 4 slides per group. The adult group had a stronger signal value per unit area compared to the juvenile. 
A

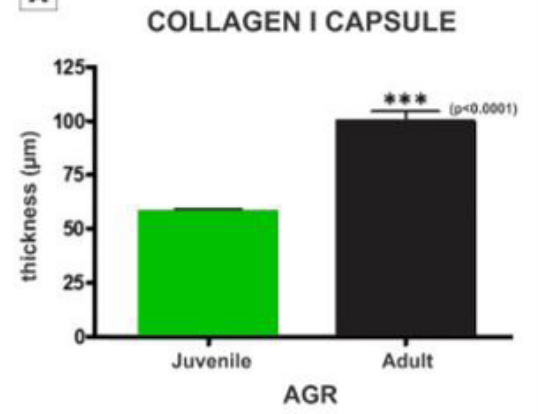

B

COLLAGEN III CAPSULE

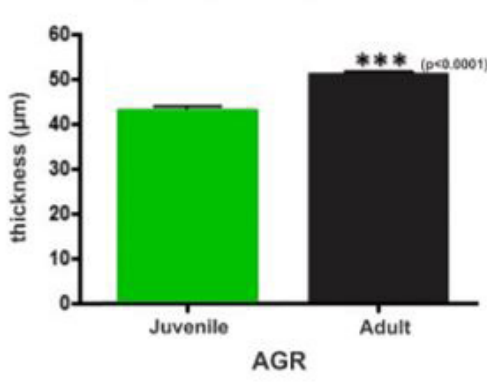

Figure 5. Capsule thickness of immunostained Collagen (A) Type I (B) Type III]. Capsule thickness were significantly higher in adult AGR compared to the juvenile AGR using 4 slides per group. Values expressed as mean \pm SEM.
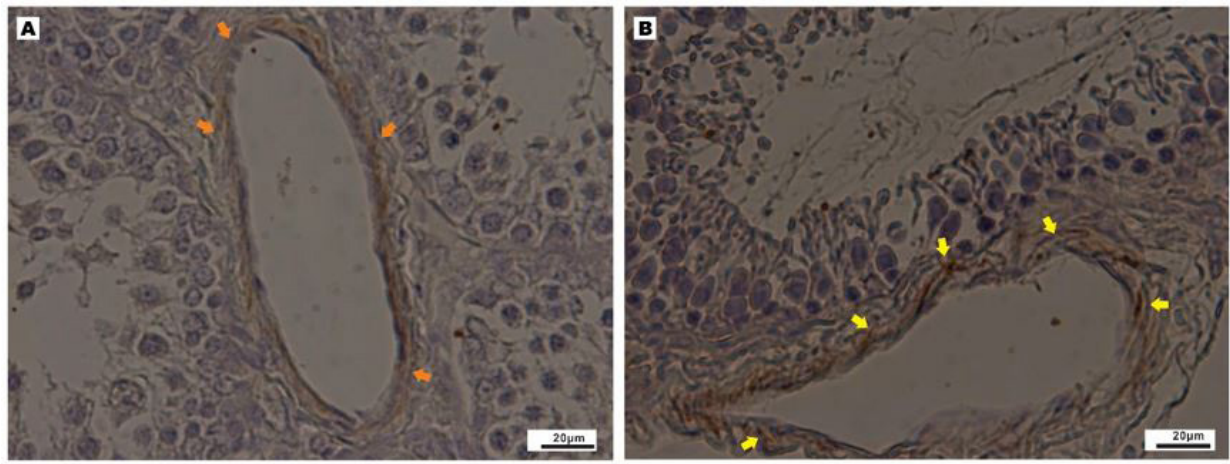

C

GFAP Signal Intensity

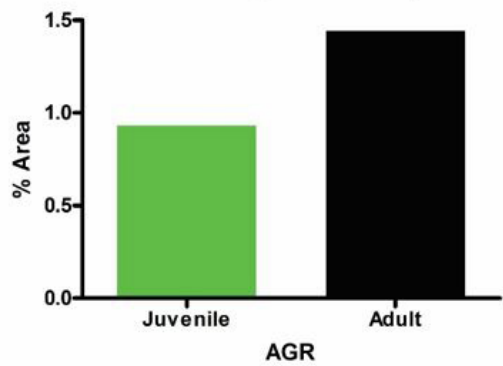

Figure 6. Glial Fibrillary Acid Protein (GFAP) expressions in AGR testis (Mag. x630). (A) GFAP immunopositive astrocyte-like cells in the juvenile testis around the blood vessel (arrows); (B) GFAP immunopositive astrocyte-like cells with tiny processes extending around the region of the blood vessel (arrows) in the adult AGR testis; (C) GFAP signal intensity of the AGR testis using 4 slides per group. The adult group had higher signal values compared to the juvenile.

the tail of the spermatozoa also immune-positive to type I Collagen (Figures 4B and C).

Collagen Type III: Immuno-expressions of collagen type III in both age groups were similar to that of the collagen type I (Figures 4D and E). The adult AGR testis had a greater signal intensity for collagen type III than the juvenile group (Figure 4F).

Collagen Capsule thickness: The thickness of the collagen types I and III stained testicular capsules were significantly higher in the adult group than in the juvenile group (Figures 5A and 5B).

GFAP IHC Studies: GFAP expressions in the testicular tissue were confined to perivascular regions in the interstitial spaces in both juvenile and adult AGR (Figures 6A and 6B). The signal intensity of GFAP-positive cells was higher in the adult group than in the juvenile group (Figure 6C).
Neuronal infrastructure of the AGR testis: The neuronal infrastructure of this rodent's testis was demonstrated with p75 NGF-positive immunostaining along the interstitial spaces of the seminiferous tubules and also in the basement membrane of both juvenile and adult groups (Figures 7A and 7B). Several spermatocytes in the tubules also showed positive signals for anti-p75 NGF antibody. The intensity of the signals appeared to be higher in the juvenile group than in the adult group (Figure 7C).

\section{Discussions}

The cytoarchitecture of the testes as revealed by $\mathrm{H} \& \mathrm{E}$ is typical for the AGR, (OKE, 1985, 1988), with the juvenile testis showing little or no spermatozoa in the lumen of the seminiferous tubule. Juvenile AGRs are sexually immature 

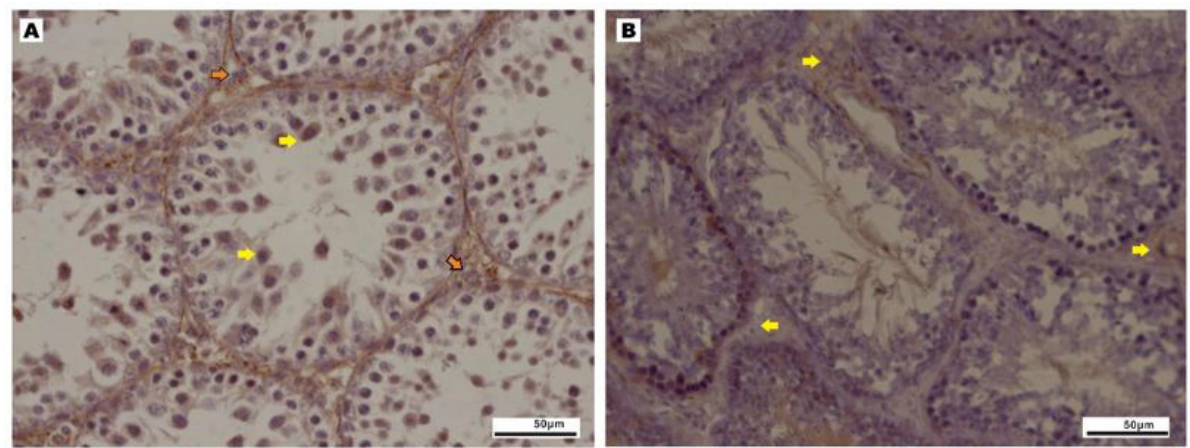

C.

p75 NGF Signal Intensity

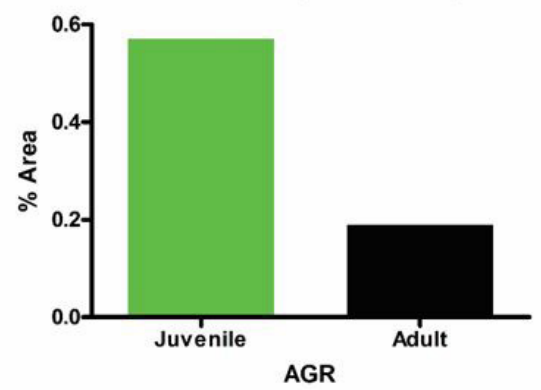

Figure 7.p75 NGF immunostaining of the AGR testis (Mag. x400). (A) immunolocalization of the p75 NGF-positive cells across the interstitial spaces of the seminiferous tubules (orange arrows) and primary spermatocytes (yellow arrows) in the juvenile testis; (B) p75 NGF immunopositive cells in the interstitial spaces of the adult testis (yellow arrows); (C) weaker p75 NGF signal intensity in adult AGR testis compared to juveniles using 4 slides per group.

as against their adult counterparts who are sexually matured as evidenced by the presence of spermatozoa in the lumen of their seminiferous tubules. The smaller values of the seminiferous tubular diameter and luminal diameter in the juvenile AGR as compared with the adult group may be as a result of sexual immaturity of these rats. Seminiferous tubule basement membrane plays an important role in spermatogenesis (KAHSAI, ENDERS, GUNWAR et al., 1997). In the present study, the organization of types I and III collagen of the AGR was investigated. Collagens are known to develop unto maturity and function in reproduction (ENDERS, KAHSAI, LIAN et al., 1995; HARVEY, PERRY, ZHENG et al., 2006). Nonetheless, the ultrastructural organization of collagen vary substantially between animals and even between different parts of the same animal (PARRY and CRAIG, 2008). However, immunohistochemistry was a more sensitive technique which characterized the collagen I and III across both age groups. It is to be noted that the collagen expression was more intense in the adult group than the juvenile. This may suggest progressive increase in collagen density; buttressing the fact that collagen provides the needed structural and metabolic support, and tensile strength necessary for sexual maturity and spermatogenesis (ENDERS, KAHSAI, LIAN et al., 1995; HARVEY, PERRY, ZHENG et al., 2006). Development of the testes in the mammalian embryo requires the formation and assembly of several cell types that allow these organs to achieve their roles in male reproduction and endocrine regulation of which collagen plays an important role (ZHU, TANG, SU et al., $2015)$. In this light, collagen types I and III IHC expressions and density can be used as markers to indicate degree of sexual maturity in the testis. Whereas collagen expression increases from juvenile to adult, the glial and neuronal expression reduces. The latter observation agrees with the findings of Olude, Mustapha, Aderounmu et al. (2015) where glial and neuronal populations were noted to decrease with age in the AGR brain. There was immuno-localization of GFAPpositive cells in the web loose connective tissue of the testis around blood vessels. These GFAP-positive cells may be perivascular astrocytes similar to those described in the AGR brain (OLUDE, MUSTAPHA, ADEROUNMU et al., 2015). Astrocytes have been known to perform many functions in the central nervous system, among which are the astrocyte end-feet encircling the endothelial cells that form the bloodbrain barrier (SOFRONIEW and VINTERS, 2010). Its presence therefore in the interstitial spaces of the testis further suggests that Leydig cells located in the interstitium may play a part in the blood-testis barrier (HOLASH, HARIK, PERRY et al., 1993). This is however contrary to previous belief that the blood-testis barrier is formed solely by the Sertoli cell (YOUNG, LOWE, STEVENS et al., 2013). The expression of GFAP perivascular astrocyte-like cells in the AGR testis may be vital to the immunity and functions of this tissue.

In the rat testis, neuropeptide receptors have been detected in the tunica albuginea and around the intracapsular blood vessels (RAUCHENWALD, STEERS and DESJARDINS, 1995; PROPERZI, CORDESCHI and FRANCAVILLA, 1992; KOPP, ZHANG and HOKFELT, 1997), with profound effects on testicular blood flow (COLLIN, ENFÄLT, ASTRÖM et al., 1998). In this study, using IHC methods, we detected both immunoreactive cells for the neuronal marker p75 NGF in perivascular regions, along with age-related differences as shown in our colorimetric density studies. Such differences 
have been reported in the Rhesus Monkey where immature Monkeys were thought to have intrinsic neuron-like cell bodies only in the testes until about 3 years of age, while those of the adult Monkeys were thought to be representing mainly the extrinsic innervation. They also became more prominent after the pubertal increase in LH and testosterone levels (FRUNGIERI, GONZÁLEZ-CALVAR, RUBIO et al., 1999), indicating that plasticity is influenced by hormones in neuronal cell expressions.

Neuronal cells were shown to be expressed in the loose connective tissue region as well, at the interstitial spaces which are in accordance with previous report in other rodent species (PARVINEN, PELTO-HUIKKO, SODER et al., 1992; LI, WATANABE, WENG et al., 2005). It is speculative at this time to say that these cells may be Leydig cells. The greater intensity of neuronal cell expressions in the juvenile rats suggests that they are developing rodents which need more of nervous infrastructure in order to attain maturity. In addition, the immuno-positive reaction in the spermatocytes suggests a specific role of this receptor during spermatogenesis (PARANKO, 1987). Nonetheless, the lower expression and intensity of neuronal cells seen in the fully matured adult group may be the effects of androgens on neuronal cells similar to that reported in the brain (ARAI, MURAKAMI and NISHIZUKA, 1994; SEIDL and HOLSTEIN, 1990). This insinuates that adult animals favour more of hormonal influences for proper reproductive capabilities since maturity has already been attained. Although the mechanisms governing these changes were not explored, this suggests that neuronal signals may act directly and/or indirectly to regulate testicular development and function.

\section{Conclusion}

This work has provided a clear description of the expression of connective tissue (collagen), glial and neuronal cells in the AGR testis and their possible relationship. This research is perhaps the first report on the neuronal and glial infrastructure of this rodent.

Acknowledgements: This study was supported by grant from the International Society for Neurochemistry - Committee for Aid and Education in Neurochemistry (ISN-CAEN) to FTE. Special thanks to Mrs Hasiena Ali for her excellent technical assistance as well as Dr Robert Ndou for the careful supervision given to the collagen immunohistochemical identification of this research.

\section{References}

AJAYI, SS. The biology and domestication of African giant rat (Cricetomys gambianus, Waterhouse). Nigeria: University of Ibadan, 1974. [Thesis].

ARAI, Y., MURAKAMI, S. and NISHIZUKA, M. Androgen enhances neuronal degeneration in the developing preoptic area: Apoptosis in the anteroventral periventricular nucleus. Hormones and Behavior, 1994, vol. 28, n. 4, p. 313-319. PMid:7729800. http://dx.doi. org/10.1006/hbeh.1994.1027.

CHENG, CY. and MRUK, DD. The blood-testis barrier and its implications for male contraception. Pharmacological Reviews, 2012, vol. 64, n. 1, p. 16-64. PMid:22039149. http://dx.doi.org/10.1124/ pr.110.002790.

COLLIN, O., ENFÄLT, E., ASTRÖM, M., LISSBRANT, E. and BERGH, A. Unilateral injection of neuropeptide Y decreases blood flow in the injected testis but may also increase blood flow in the contra lateral testis. Journal of Andrology, 1998, vol. 19, n. 5, p. 580-584. PMid:9796618.

DAVIDOFF, MS., MIDDENDORFF, R., KÖFÜNCÜ, E., MÜLLER, D., JEZEK, D. and HOLSTEIN, AF. Leydig cells of the human testis possess astrocyte and oligodendrocyte marker molecules. Acta Histochemica, 2002, vol. 104, n. 1, p. 39-49. PMid:11993850. http:// dx.doi.org/10.1078/0065-1281-00630.

DI LULLO, GA., SWEENEY, SM., KÖRKKÖ, J., ALA-KOKKO, L. and SAN ANTONIO, JD. Mapping the ligand-binding sites and disease-associated mutations on the most abundant protein in the human, type I collagen. The Journal of Biological Chemistry, 2002, vol. 277, n. 6, p. 4223-4231. PMid:11704682. http://dx.doi. org/10.1074/jbc.M110709200.

ENDERS, GC., KAHSAI, TZ., LIAN, G., FUNABIKI, K., KILLEN, PD. and HUDSON, BG. Developmental changes in seminiferous tubule extracellular matrix components of the mouse testis: alpha 3(IV) collagen chain expressed at the initiation of spermatogenesis. Biology of Reproduction, 1995, vol. 53, n. 6, p. 1489-1499. PMid:8562707. http://dx.doi.org/10.1095/biolreprod53.6.1489.

FIJAK, M., BHUSHAN, S. and MEINHARDT, A. Immunoprivileged sites: the testis. Methods in Molecular Biology, 2011, vol. 677, p. 459-470. PMid:20941627. http://dx.doi.org/10.1007/978-160761-869-0_29.

FRUNGIERI, MB., GONZÁLEZ-CALVAR, SI., RUBIO, M. and OZU, M. Serotonin in golden hamster testes: testicular levels, immunolocalization and role during sexual development and photoperiodic regresion-recrudescence transition. Neuroendocrinology, 1999, vol. 69, p. 299-308. PMid:10207282. http://dx.doi.org/10.1159/000054431.

HARVEY, SJ., PERRY, J., ZHENG, K., CHEN, D., SADO, Y., JEFFERSON, B., NINOMIYA, Y., JACOBS, R., HUDSON, BG. and THORNER, PS. Sequential expression of type IV collagen networks: testis as a model and relevance to spermatogenesis. American Journal of Pathology, 2006, vol. 168, n. 5, p. 1587-1597. PMid:16651625. http://dx.doi.org/10.2353/ajpath.2006.050816.

HOLASH, JA., HARIK, SI., PERRY, G. and STEWART, PA. Barrier properties of testis microvessels. Proceedings of the National Academy of Sciences of the United States of America, 1993, vol. 90, n. 23, p. 11069-11073. PMid:7902579. http://dx.doi.org/10.1073/ pnas.90.23.11069.

HOMMA, S., BEERMANN, ML. and MILLER, JB. Peripheral nerve pathology, including aberrant Schwann cell differentiation, is ameliorated by doxycycline in a laminin- $\alpha 2$-deficient mouse model of congenital muscular dystrophy. Human Molecular Genetics, 2011 , vol. 20, n. 13, p. 2662-2672. PMid:21505075. http://dx.doi. org $/ 10.1093 / \mathrm{hmg} / \mathrm{ddrl} 68$.

JUNQUEIRA, LC. and CARNEIRO, J. Basic histology: text and atlas. 11th ed. New York: McGraw-Hill, 2007. chap. 21: male reproductive system.

KAHSAI, TZ., ENDERS, GC., GUNWAR, S., BRUNMARK, C., WIESLANDER, J., KALLURI, R., ZHOU, J., NOELKEN, ME. and HUDSON, BG Seminiferous tubule basement membrane. Composition and organization of type IV collagen chains, and the linkage of alpha3(IV) and alpha5(IV) chains. The Journal of Biological Chemistry, 1997, vol. 272, n. 27, p. 17023-17032. PMid:9202017. http://dx.doi.org/10.1074/jbc.272.27.17023.

KOPP, J., ZHANG, X. and HOKFELT, T. Neuropeptide Yl receptors in the rat genital tract. Regulatory Peptides, 1997, vol. 70, n. 2-3, p. 149-160. PMid:9272627. http://dx.doi.org/10.1016/S01670115(97)00028-1.

LI, C., WATANABE, C., WENG, Q., JIN, W., FURUTA, C., SUZUKI, AK., KAWAGUCHI, M. and TAYA, K. Expression of Nerve Growth Factor (NGF), and Its Receptors TrkA and p75 in the Reproductive Organs of the Adult Male Rats. Zoological Science, 
2005, vol. 22, n. 8, p. 933-937. PMid:16141707. http://dx.doi. org/10.2108/zsj.22.933.

LODISH, H., BERK, A., MATSUDAIRA, P., KAISER, CA., KRIEGER, M., SCOTT, MP., ZIPURSKY, L. and DARNELL, J. Molecular cell biology: integrating cells into tissues. 5 th ed. New York: W. H. Freeman, 2003. p. 197-273.

JOO, MS. Cricetomys gambianus. Animal Diversity Web, 2004. Available from: <http://animaldiversity.org/accounts/Cricetomys_gambianus/>. Access in: 11 July 2016.

OKE, BO. Effect of season on the reproductive organs of the male African Giant Rat (Cricetomys gambiamus, Waterhouse) in Ibadan, Nigeria. African Journal of Ecology, 1985, vol. 23, n. 1, p. 67-70. http://dx.doi.org/10.1111/j.1365-2028.1985.tb00716.x.

OKE, BO. Some aspects of the reproductive biology of the male African giant rat (Cricetomys gambianus, Waterhouse). Ibadan: University of Ibadan, 1988. [Ph.D Thesis].

OLUDE, MA., MUSTAPHA, OA., ADEROUNMU, OA., OLOPADE, JO. and IHUNWO, AO. Astrocyte morphology, heterogeneity, and density in the developing African giant rat (Cricetomys gambianus). Frontiers in Neuroanatomy, 2015, vol. 9, p. 1-10. http://dx.doi. org/10.3389/fnana.2015.00067.

PARANKO, J. Expression of type I and III collagen during morphogenesis of fetal rat testis and ovary. The Anatomical Record, 1987, vol. 219, n. 1, p. 91-101. PMid:3688465. http://dx.doi. org/10.1002/ar.1092190115.

PARRY, DA. and CRAIG, AS. Ultrastructure of the connective tissue matrix: growth and development of collagen fibrils in connective tissue. In RUGGERI, A. and MOTTA A. The Hague: Martinus Nijhoff, 2008. p. 34-62.

PARVINEN, M., PELTO-HUIKKO, M., SODER, A., SCHULTZ, R., KAIPIA, A., MALI, P., TOPPARI, J., HAKOVIRTA, H., LONNEBERG, P., RITZEN, EM., EBENDAL, T., OLSON, L., HOKFELT, T. and PARSSON, H. Expression of nerve growth factor and its receptor in rat seminiferous epithelium: specific function at the onset of meiosis. The Journal of Cell Biology, 1992, vol. 117, n. 3, p. 629-641. PMid:1315318. http://dx.doi.org/10.1083/jcb.117.3.629.
PASQUINI, C., SPURGEON, T. and PASQUINI, S. Anatomy of domestic animals: systemic and regional approach. 9th ed. Sudz Publishing, 1997.

PROPERZI, G., CORDESCHI, G. and FRANCAVILLA, S. Postnatal development and distribution of peptide containing nerves in the genital system of the male rat: an immunohistochemical study. Histochemistry, 1992, vol. 97, n. 1, p. 61-68. PMid:1618640. http:// dx.doi.org/10.1007/BF00271282.

RAUCHENWALD, M., STEERS, WD. and DESJARDINS, C. Efferent innervation of the rat testis. Biology of Reproduction, 1995, vol. 52, n. 5, p. 1136-1143. PMid:7542932. http://dx.doi.org/10.1095/ biolreprod52.5.1136.

ROBILLARD, KR., HOQUE, MT. and BENDAYAN, R. Expression of ATP-Binding Cassette Membrane Transporters in Rodent and Human Sertoli Cells: Relevance to the Permeability of Antiretroviral Therapy at the Blood-Testis Barrier. The Journal of Pharmacology and Experimental Therapentics, 2012, vol. 340, n. 1, p. 96-108. PMid:21990609. http://dx.doi.org/10.1124/jpet.111.186916.

SEIDL, K. and HOLSTEIN, AF. Evidence for the presence of nerve growth factor (NGF) and NGF receptors in human testis. Cell and Tissue Research, 1990, vol. 261, n. 3, p. 549-554. PMid:2173974. http://dx.doi.org/10.1007/BF00313534.

SOFRONIEW, MV. and VINTERS, HV. Astrocytes: biology and pathology. Acta Neuropathologica, 2010, vol. 119, n. 1, p. 7-35. PMid:20012068. http://dx.doi.org/10.1007/s00401-009-0619-8.

YOUNG, B., LOWE, JS., STEVENS, A. and HEATH, JW. Wheater's functional histology: a text and colour atlas: male reproductive system. 5th ed. Churchill Livingstone, 2013. p. 337-350.

ZHU, CC., TANG, B., SU, J., ZHAO, H., BU, X., LI, Z., ZHAO, J., GONG, WD., WU, ZQ., YAO, LB., LI, W. and ZHANG, YQ. Abnormal Accumulation of Collagen Type I Due to the Loss of Discoidin Domain Receptor 2 (Ddr2) Promotes Testicular Interstitial Dysfunction. PLoS One, 2015, vol. 10, n. 7, p. e0131947. PMid:26158267. http:// dx.doi.org/10.1371/journal.pone.0131947.

Received March 21, 2017 Accepted August 26, 2017 